\title{
Moslem Entrepreneur Behavior and its Effect on Knowledge, Network and Performance
}

\author{
Wiwik Lestari', Sri Lestari K², Djoko Budhi Setyawan ${ }^{3}$ and Achmad Saiful Ulum ${ }^{4}$
}

\author{
${ }^{1}$ STIE Perbanas Surabaya, Indonesia \\ ${ }^{2}$ STIE Perbanas Surabaya, Indonesia \\ ${ }^{3}$ STIE Perbanas Surabaya, Indonesia \\ ${ }^{4}$ STIE Perbanas Surabaya, Indonesia
}

\begin{abstract}
The research aim is study entrepreneurial behavior based on Islamic taught. Islam encourage learning and networking. The first taught of Alqur'an is "Iqra!" means read or learn! Entrepreneurs need to equip themselves with entrepreneurial knowledge and experience so called entrepreneurial literacy. Knowledge here including financial, innovation and development of process. Moslem also taught to widespread networking in order to gather "rizq" and prolong the life. This study is preliminary research which has high content on validity and reliability test. However, we try to find the relationship between religion, knowledge and networking and their effect to performance. Samples are Moslem entrepreneur from several region of East Java including Madura, Malang, Probolinggo, Banyuwangi, Blitar, Ponorogo and Gerbangkertasusila. By using partial least squared, we found that religion has direct and indirect effect on performance through knowledge and network.
\end{abstract}

Keywords: Islamic entrepreneurship, religion effect

\section{Introduction}

There is a simple idiom that knowledge without religion is blind, religion without knowledge is lame. Both need to be run in balance. On entrepreneurship context, has the entrepreneur run his/her business based on sufficient religion and knowledge?

Islam encourage learning and networking. The first taught of Alqur'an is "Iqra!" means read or learn! Entrepreneurs need to equip themselves with entrepreneurial knowledge and experience so called entrepreneurial literacy. Knowledge here including financial, innovation and development of process. Moslem also taught to widespread networking in order to gather "rizq" and prolong the age. Regarding business, performance is a proof of business. SME's need to gather profit to survive.

Recently, Islamic entrepreneurship concepts are many propose by scholar, rather the empirical study need many. This study performs the effect of this two basic taught of Islam on SMEs performance.

The rest of the paper consist of literature review on Islamic entrepreneurship, entrepreneurship literacy and networking. On this section, we also developed hypotheses. Next section is methodology consist of variable and measurement, sampling and validity and reliability test. The third section is result and discussion and followed by conclusion and limitation. The last is future research opportunity.

Islamic Entrepreneurship. Conceptual development and empirical studies on Islamic entrepreneurship have more attentions recently. The point is that Islamic business or entrepreneurship is a business that not only seeks profit but also pursuing falah (non-financial benefit) for humans being and the universe. Islam encourages entrepreneurship. The Hadith stated that nine out of ten fortune doors were on commerce activity. Although some record it as a weak hadith, it contains the truth. Ramadani, Dana, Ratten, \& Tahiri (2015) suggested that Islam encourages Moslem to become rich in the right way. Entrepreneurial character according to Ratten, Alamanda, Ramadani, Hashani, \& Anggadwita (2017) is like the Prophet Muhammad, peace upon him, who is Amanah, Fathonah, Siddiq and Tabligh.

Davis (2015) describes the behavior of Islamic entrepreneurship is to give benefit entrepreneurs to live in more virtuous life and also give benefit to community to support good work (for example, giving alms 
to those who need or help build mosques). Pursuing entrepreneurial success does not only a means of pleasing oneself, but also must be considered as a spiritual act in helping others to be successful (Dana, 2009). It is a challenge for researchers to examine whether Muslim entrepreneurs have implemented Islamic thoughts when doing business.

Several studies on Islamic religiosity are proposed by Akhter \& Sobhani (2016) and Nabi, Liñán, \& Kirby (2011) but still using religiosity concept in general. The Indonesian Accountant Association develop principles of sharia transactions which is including $u k h u w a h$ (brotherhood, 'adalah (justice = fairness), maslahah, tawazzun and syumuliyah (IAI, 2012). This concept is more suitable for measuring entrepreneurial religiosity because it is basically a concept that involves business transactions (Lestari, Salim, \& Sudarma, 2014). The concept is still in the form of thought and still need to empirically study. Regarding to the practical teachings of doing business, Islam encourage two basic things and have not been widely studied, namely the teaching about seeking knowledge and doing silaturrahim (networking). Muslims are taught to always study. Entrepreneurship needs to have knowledge. Excellence in business knowledge is needed to identify strengths, weaknesses, opportunities and threats related to business that can ultimately help in formulating policies and strategies needed to make a business successful (Hoque, Mamun, \& Abdullah, 2014). On the other hand, silaturrahim also as one of the main teachings of Islam in business can be connoted as building and maintaining networks or good relations with stakeholders. In today's digital era, networking is related to information technology usage. The use of gadgets and the use of social media seem very helpful for businesses both when business need supplies and especially when marketing the products.

Entrepreneurship Literacy. Entrepreneurship is the process of simultaneously decision-making activities regarding the acquisition, allocation and utilization of resources. For this purpose, entrepreneurs need to have knowledge relevant to their business. This paper proposes the use of the term entrepreneurial literacy. The term that is also widely used is competence. Literacy implies knowledge, attitude and implementation (Huston, 2010).

Financial literacy is a concept considered closest to entrepreneur's knowledge. Entrepreneurship business activities have direct and indirect financial implications so that entrepreneur must be financially literate (Oseifuah, 2010). Financial literacy is considered as one of the critical managerial competencies in SME companies and development (Eniola \& Entebang, 2017). Some of the concepts of financial literacy for entrepreneurship are used by Njaramba et al. (2015) on immigrant women entrepreneurs in Australia consisting of financial knowledge on money transacting methods and financial knowledge on saving and budgeting. The financial literacy proposed by Gathungu \& Sabana (2018) also refers to the concept of individual financial literacy, including Financial Management, Debt Literacy, Saving Literacy, Investment Literacy and Insurance Literacy. Not all are suitable applied in entrepreneurship primarily about saving and insurance literacy.

In this study, we propose the term literacy because it is related to knowledge which is implemented as a definition of literacy in general. At present, we continue to study this concept in order be a robust concept theoretically and empirically.

Back to the Islamic taught about important of knowledge, Muslim entrepreneurs should be knowledgeable and apply them in their business. The concept of entrepreneurial literacy reviewed in this paper is knowledge about finance, products, innovation, and marketing.

H1. Religion which is proxied as the implementation of Islamic Transaction Principles encourages entrepreneurs to have Muslim entrepreneurial knowledge (literacy).

H2. Entrepreneurial literacy is able to improve Muslim entrepreneurial performance

Networking. The use of the term networking has several equivalents, among others, as a social relationship. Islam strongly encourages networking namely silaturrahim or silaturrahmi. Many 
Islamic teachings regarding the importance and benefits of silaturrahim include increasing fortune, prolonging life.

Allah Ta'ala ordered to enhance relationship among Moslem. Al-Quran clearly state "Worship Allah and do not compare Him with anything. And be good to fathers, relatives, orphans, poor people, close neighbors and distant neighbors, and colleagues, Ibn Sabil and your servant. Verily Allah does not like those who are proud and pride themselves "(Surat An Nisa: 36). Prophet Muhammad, peace upon him also said "Whoever wants extend his/her wealthiness and extend his/her life, therefore, connect the relationship" (Bukhari - Muslim).

Business dynamics are very fast changing, entrepreneurial research also needs to adapt. Yu, Hao, Ahlstrom, Si, \& Liang (2014)showed that the business turbulence affects business performance, especially new products. Entrepreneurs also need to have ability to adapt to changes in business conditions. However, still not many studies focusing on the use of social media as networking support. Even if there is, it mostly only on marketing. In the business context, networking (silaturrahim) is should be with customers, suppliers, peer and also the government (Nmadu, 2011). Every business prioritizes their relationships with customers since customer purchases and repurchases make the company alive and grow. Networking with suppliers ensures that supplies from suppliers are on time, without complaints, and supporting sales. Networking with business colleagues is very important especially for entrepreneurs because in business practices, opportunities can sometimes be fulfilled by cooperating with business partners. Banerjee (2005) proposes relationships and exchanges of capabilities between similar entrepreneurial clusters will increase entrepreneurial competence. Networking with local government is important to update new rules, technical and non-technical assistance that is usually provided by the authorities to encourage entrepreneurship.

According to Stam, Arzlanian, \& Elfring (2014) social capital, or resources embedded in the private network of entrepreneurs, is essential for the performance of small companies. For example, network connections allow entrepreneurs to identify new business opportunities, get resources below market prices, and secure legitimacy from external stakeholders.

The use of the internet today is inevitable by the business world. Empirical evidence shows a significant increase in e-commerce activities. In addition, with the change, increasing the use of information technology requires a separate strategy for entrepreneurs to survive, develop and win in competition. Thus, the proposed hypothesis is

H1. Religion which is proxied as the application of Islamic transaction principles encourages entrepreneurs to improve networking

H2. Networking (silaturrahim) can improve Muslim entrepreneurial performance.

H3. Religion, knowledge and networking directly and indirectly improve strategies and ultimately have an impact on performance.

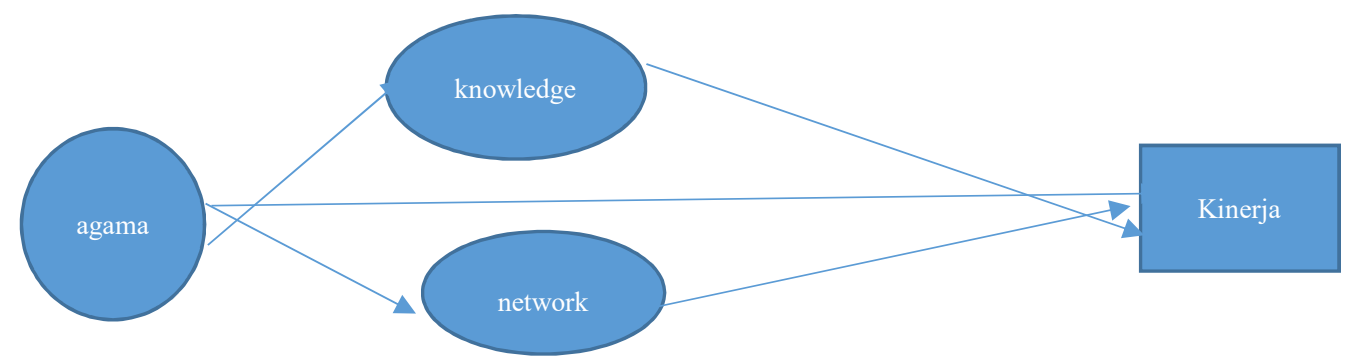

Figure 1. Structural Model 


\section{Research Methodology}

This research was conducted in the area of East Java which has 9.59 million SMEs in 2018 (source: Sureplus, August 19, 2018). The sample is limited based on the criteria of Muslim Entrepreneurs, at least has been doing business for 3 years and/or has 4 employees. The variables that has been studied are

a. Entrepreneurial performance. Entrepreneurial performance is generally difficult to measure considering that seldom do records. This is based on the opinion that there is a strong and valid correlation between objective and subjective performance data (Torugsa, O'Donohue, \& Hecker, 2012), this study measures performance more towards perceptual performance on business growth and turnover.

b. Religion is proxied by the implementation of the principle of sharia transactions. There are 5 indicators namely ukhuwah (brotherhood), 'adalah (fairness = justice), maslahah (benefit), tawazzun (balance) and syumuliyah (universal). Technically, there are 20 statement items that are carefully developed through content analysis. The answer choices provided are from $1=$ never, to $5=$ always. So basically, the items proposed are measuring the implementation of sharia transactions. These twenty items are grouped into five indicators. This indicator is a formative indicator that should not be left one of them. Thus, the religious variable is a second order variable formed from the five indicators. The results are as table 1 .

Table 1. Construct Measurement of Religion

\begin{tabular}{llrrrr}
\hline & & Loading & p-value & VIF & Cronbach \\
\hline Lv_ukh & Ukhuwah & 0.546 & $<0.001$ & 1.105 & 0.607 \\
Lv_adl & 'adalah & 0.623 & $<0.001$ & 1.190 & \\
Lv_masl & Maslahah & 0.736 & $<0.001$ & 1.370 & \\
Lv_taw & Tawazun & 0.596 & $<0.001$ & 1.174 & \\
Lv_syum & Syumuliyah & 0.611 & $<0.001$ & 1.265 & \\
\hline
\end{tabular}

a. Variables of knowledge or literacy are measured persuasively by criteria, $1=$ incapable, $2=$ rather capable, $3=$ capable, $4=$ Advanced. This variable is also a development of a measure of entrepreneurial literacy that should be owned by Muslim entrepreneurs. Items and results are in table 2.

Table 2. Construct Measurement of entrepreneurship Literacy (knowledge)

\begin{tabular}{llrrrr}
\hline & & Loading & p-value & VIF & Cronbach \\
\hline D.1 & Develop business budget & 0.835 & 0.001 & 2.365 & 0.787 \\
D.3 & Develop financial Report & 0.770 & 0.003 & 2.037 & \\
D.5 & Develop product innovation & 0.406 & 0.076 & 1.157 & \\
D.7 & Operate Internet & 0.751 & 0.004 & 1.848 & \\
D.14 & Social media (WhatsApp; twitter; & 0.774 & 0.003 & 1.899 & \\
& etc.) & 0.612 & 0.015 & 1.293 & \\
D.16 & Develop business Strategy & &
\end{tabular}

b. Variable networking or silaturrahim, measured perceptively about the importance of business relations with their stakeholders. The answer choices provided are $1=$ not important, 2 = rather important, $3=$ important and $4=$ very important. Items and results are in table 3. 
Table 3. Construct Measurement of Networking

\begin{tabular}{|c|c|c|c|c|c|}
\hline & & loading & p-value & VIF & $\begin{array}{c}\text { Cronbach } \\
\alpha\end{array}$ \\
\hline D.8 & Internet uses of Business & 0.740 & 0.002 & 2.246 & 0.744 \\
\hline D.9 & Interact with consumer & 0.441 & 0.047 & 1.526 & \\
\hline D.10 & Interact with supplier & 0.639 & 0.007 & 1.716 & \\
\hline D.11 & Interact with government & 0.588 & 0.013 & 1.288 & \\
\hline D.12 & interact with business peer & 0.650 & 0.007 & 1.533 & \\
\hline D.13 & $\begin{array}{l}\text { Interact with bank or financial } \\
\text { institution }\end{array}$ & 0.674 & 0.005 & 1.548 & \\
\hline D.15 & Social media user for business & 0.650 & 0.007 & 2.105 & \\
\hline
\end{tabular}

Overall testing of the validity and reliability of measurements shows that all constructs are valid and reliable.

\section{Result and Discussion}

The study distributes 250 questionnaires to Muslim entrepreneurs around East Java. Out of 250 who were distributed, filled and can be analyzed of 103, from Madura, Malang, Probolinggo, Blitas, Banyuwangi, Pasuruan Ponorogo and Gerbangkertasusila. So, the response rate is $41 \%$. From the data obtained, $52 \%$ of respondents are men and the rest are women. This shows that there is an equal role between men and women in seeking fortune through entrepreneurship. Average age of business is 9.4 years. This shows that entrepreneurs are not nascent entrepreneurs who only try to open a business.

There were $82 \%$ of respondents married, $13 \%$ were single and, $5 \%$ were widowed. Meanwhile, $60 \%$ of respondents reported a sale under 15 million Rupiahs per month or approximately less than US \$1,000. It's shows that most are small businesses. Meanwhile, in terms of assets, $30 \%$ of respondents stated that their assets were below Rp. 15 million.

The test results using PLS, all hypotheses are accepted. Religion has a significant positive effect on literacy improvement, networking and ultimately can drive positive performance.

Table 4. Path coefficient dan $p$-value

\begin{tabular}{lrrr}
\hline & $\begin{array}{c}\text { Knowledge } \\
\text { (literacy) }\end{array}$ & networking & \multicolumn{1}{c}{ religion } \\
\hline Knowledge & & & 0.313 \\
(literacy) & & & $(<0.001)$ \\
Networking & & & 0.242 \\
& & & $(0.005)$ \\
performance & 0.186 & -0.181 & 0.180 \\
& $(0.025)$ & $(0.027)$ & $(0.029)$ \\
\hline
\end{tabular}

It can be said that the respondents of Muslim entrepreneurs have applied the principle of Islamic transactions. In table 1, the first and second highest loading are Maslahah and adalah principle. Maslahah means that entrepreneurs when doing business need to consider not only benefits for themselves and their families, but more broadly that their business can benefit the community. Meanwhile, 'adalah principle is the most widely implemented by Muslim businessmen regarding honesty, quality and fairness (Lestari et al., 2014). 


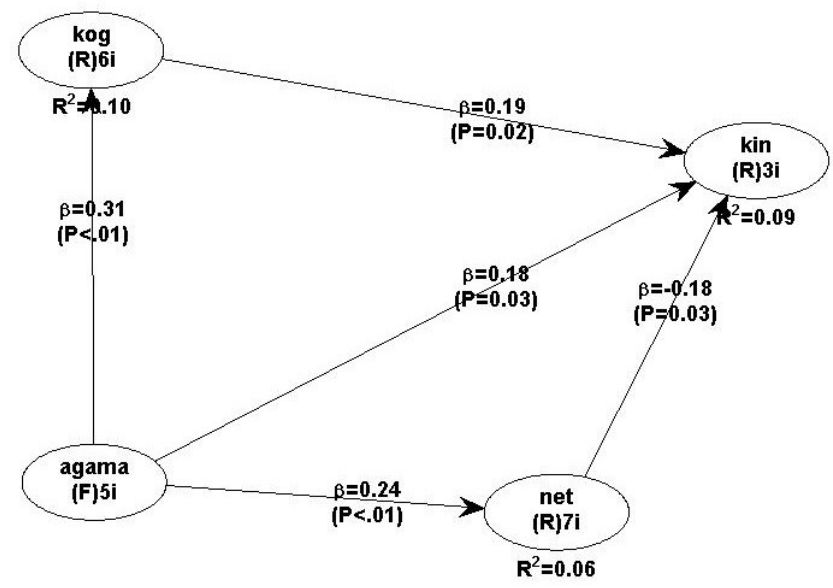

Figure 2. Variables relationship

Furthermore, it is very clear that Islam taught on pursuing knowledge and applying them on daily business is proven significantly implemented by respondent. In other words, religion has positive significant effect on entrepreneurship literacy. Descriptively, the highest loading factor is knowledge on making budget. Respondents have been very good at making business budgets, since they have been in business for a long time. While the lowest is on product innovation and strategy development. Therefore, these two aspects need to be improved.

In terms of networking (silaturrahim), the highest loading is the importance of the internet. It is clear that Muslim entrepreneurs are aware that the digital era 4.0 is very important and needs to be anticipated. Meanwhile, the lowest loading is the relationship with consumers. It is needing a big concern since consumer is always important for business. However, it is needs to be confirmed, whether the existence of the internet has reduced the need for physical interaction with consumers.

In general, this research proves that the higher the application of sharia principles, the higher increasing on entrepreneurial knowledge. Likewise, the higher the application of religion, the greater the need for networking which ultimately helped improve Muslim entrepreneurial performance.

Interesting results are shown in a significant negative relationship between networking (silaturrahim) and performance. It can be understood that networking sometimes requires cost. Prophet Muhammad peace upon him, gave an example that he loved his friends, gave gifts and sometime received a gift. It seems that it needs to be considered that for entrepreneurs this still needs to be done but remains in the corridor of its business budget so as not to burden and create negative performance.

\section{Conclusion}

From a series of tests using PLS, the results showed that all hypotheses are accepted. Religion has a significant positive effect on literacy improvement, networking and ultimately drive positive performance. Partially, knowledge (literacy) is positively related to performance, but networking (silaturrahim) is negatively related to performance. Islam encourage learning and networking activity and proven has been carried out by Muslim entrepreneur respondents. Unfortunately, too much networking produces lower performance since networking basically need costs.

Furthermore, there are several notes for suggestions, among others, aspects that need to be improved by Muslim entrepreneurs. Regarding literacy, the lowest is about product innovation and strategy development. Therefore, these two aspects of literacy need to be improved. For governments that support entrepreneurship, aspects of innovation and the ability to develop strategies need to improve. 
Limitations and future research opportunities. First, performance measures still in conventional business performance approach. Researchers still need to develop sharia business measurement instruments that should not only profit but also falah. Second, this research is still in initial stage, where the data to prove the hypothesis is still a survey that is generalized so that it has not been able to explore specific conditions that may exist. In the future, it is necessary to confirm with in-depth interviews to obtained participant's respond specifically, in order to gather the description of religion implementation which is must be different from each other.

\section{References}

Banerjee, P. (2005). Corporate Governance and Competence in SME' s in India, 1(June), 43-49.

Dana, L. P. (2009). Religion as an Explanatory Variable for Entrepreneurship. The International Journal of Entrepreneurship and Innovation. https://doi.org/10.5367/000000009788161280

Davis, M. (2015). Entrepreneurship from an Islamic Perspective. Journal of Business Ethics, 130(1), 199-208. https://doi.org/10.1007/s10551-014-2223-7

Hoque, N., Mamun, A., \& Abdullah, M. A. M. (2014). Dynamics and traits of entrepreneurship: an Islamic approach. World Journal of Entrepreneurship, Management and Sustainable Development, 10(2), 128-142. https://doi.org/10.1108/WJEMSD-04-2013-0027

IAI. (2012). Kerangka Dasar Penyusunan dan Penyajian Laporan Keuangan Syariah. British Journal of Economics, Finance and Management Sciences. https://doi.org/10.1007/s13398-014-0173-7.2

Lestari, W., Salim, U., \& Sudarma, M. (2014). Determinants of Investment Decision among Moslem Entrepreneurs. International Journal of Business and Management, 8(January 2014), 1-16. https://doi.org/10.7718/iamure.ijbm.v8i1.733

Nabi, G., Liñán, F., \& Kirby, D. A. (2011). An empirical survey of individual consumer, business firm and financial institution attitudes towards Islamic methods of finance". Journal of Management Development, 26(11), 428-440. Retrieved from http://dx.doi.org/10.1108/02621710710748266\%5Cnhttp://

Nmadu, T. M. (2011). Enhancing Women's Participation in Formal and Informal Sectors of Nigeria's Economy Through Entrepreneurship Literacy. Journal of Business Diversity, 11(1), 87-98. Retrieved

from http://search.ebscohost.com/login.aspx?direct=true \&db=buh\&AN=82037004\&site=ehost-live

Stam, W., Arzlanian, S., \& Elfring, T. (2014). Social capital of entrepreneurs and small firm performance: A meta-analysis of contextual and methodological moderators. Journal of Business Venturing, 29(1), 152-173. https://doi.org/10.1016/j.jbusvent.2013.01.002

Torugsa, N. A., O’Donohue, W., \& Hecker, R. (2012). Capabilities, Proactive CSR and Financial Performance in SMEs: Empirical Evidence from an Australian Manufacturing Industry Sector. Journal of Business Ethics. https://doi.org/10.1007/s10551-011-1141-1

Yu, B., Hao, S., Ahlstrom, D., Si, S., \& Liang, D. (2014). Entrepreneurial firms' network competence, technological capability, and new product development performance. Asia Pacific Journal of Management. https://doi.org/10.1007/s10490-013-9365-5 